\title{
Analisis komparasi metode pembinaan cabang olahraga bulutangkis antara Yogyakarta Indonesia dengan Ottapalam India
}

\author{
Mansur Mansur *, Faidillah Kurniawan, Andri Wijaya, Suharjana Suharjana \\ Program Studi Pendidikan Kepelatihan Olahraga, Universitas Negeri Yogyakarta \\ Jalan Colombo No.1, Karangmalang, Yogyakarta 55281, Indonesia \\ * Corresponding Author. Email: mansur@uny.ac.id
}

Received: 26 May 2020; Revised: 8 October 2020; Accepted: 20 November 2020

\begin{abstract}
Abstrak: Penelitian ini bertujuan untuk mengetahui perbandingan metode pembinaan cabang bulutangkis antara Yogyakarta, Indonesia dengan Ottapalam, India. Penelitian ini menggunakan metode deskriptif, Desain yang digunakan dalam penelitian ini adalah observasi lapangan. Populasi dalam penelitian ini adalah pemain di CSN Badminton Academy India yang berjumlah adalah 32 atlet dan atlet di PB Wiratama Jaya Yogyakarta yang berjumlah 28 atlet. Pengambilan sampel dalam penelitian ini dengan menggunakan yaitu human instrument atau yang dikenal sebagai peneliti kualititatif. Peneliti merupakan instrumen itu sendiri, dengan kata lain peneliti juga perlu "divalidasi" seberapa jauh peneliti kualitatif siap melakukan penelitian yang selanjutnya turun ke lapangan. Adapun jenis data yang digunakan pada penelitian ini yaitu data sekunder dan data primer dari kedua klub. Hasil penelitian menunjukkan bahwa (1) PB. Wiratama Jaya Yogyakarta dan CSN Badminton Academy India memiliki jenis Latihan shadow yang sedikit berbeda. CSN Badminton Academy India menggunakan teknik lompatan saat kembali ke posisi awal. Sedangkan PB. Wiratama Jaya Yogyakarta tidak menggunakan teknik lompatan. (2) PB. Wiratama Jaya Yogyakarta memiliki atlet yang patuh terhadap peraturan karena persaingan yang ketat. Sedangkan CSN Badminton Academy India memiliki atlet yang kurang patuh terhadap jam berlatih yang disebabkan jauhnya tempat latihan. (3) CSN Badminton Academy India memiliki susunan kepengurusan yang baik serta memiliki bukti fisik. Sedangkan PB. Wiratama Jaya Yogyakarta kurang melengkapi bukti fisik kepengurusan.
\end{abstract}

Kata kunci: metode pembinaan, Yogyakarta Indonesia, Ottapalam India

\section{A comparative analysis on the badminton coaching between Yogyakarta, Indonesia and Ottapalam, India}

\begin{abstract}
This study aims to compare the method of developing badminton branches between Yogyakarta, Indonesia and Ottapalam, India. This research uses descriptive method, the design used in this study is field observation. The population in this study were 32 players at CSN Badminton Academy in India and 28 athletes in PB Wiratama Jaya Yogyakarta. Sampling in this study using human instruments or known as qualitative researchers. The researcher is the instrument itself, in other words the researcher also needs to be "validated" to what extent the qualitative researcher is ready to conduct research which then goes to the field. The types of data used in this study are secondary data and primary data from the two clubs. The results showed that (1) PB. Wiratama Jaya Yogyakarta and CSN Badminton Academy India have a slightly different type of shadow training. CSN Badminton Academy India uses the jump technique when returning to starting position. Whereas PB. Wiratama Jaya Yogyakarta does not use jumping techniques. (2) PB. Wiratama Jaya Yogyakarta has athletes who abide by regulations because of intense competition. Whereas CSN Badminton Academy India has athletes who are not obedient to the practice hours due to the training grounds. (3) CSN Badminton Academy India has a good management structure and physical evidence. Whereas PB. Wiratama Jaya Yogyakarta did not complete the management's physical evidence.
\end{abstract}

Keywords: Coaching methods, Yogyakarta Indonesia, Ottapalam India

How to Cite: Mansur, M., Kurniawan, F., Wijaya, A., \& Suharjana, S. (2020). Perbandingan metode pembinaan cabang bulutangkis antara Yogyakarta Indonesia dengan Ottapalam India. Jurnal Keolahragaan, 8(2), 204-215. doi:https://doi.org/10.21831/jk.v8i2.31998 


\section{PENDAHULUAN}

Bulutangkis merupakan olahraga yang dimainkan dengan menggunakan net, raket, dan bola dengan teknik pemukulan yang bervariasi mulai dari yang relatif lambat hingga yang cepat disertai dengan gerakan tipuan (Grice, 1996). Bulutangkis adalah salah satu cabang olah raga yang populer dan banyak diminati oleh masyarakat di berbagai negara, bahkan bulutangkis sendiri merupakan cabang olahraga terpopuler nomer dua di dunia setelah cabang olahraga sepak bola. Adapun negara-negara yang memiliki pemain bulutangkis dengan keterampilan yang sangat bagus antara lain, Cina, Indonesia, Jepang, Denmark, Malaysia dan India. Namun dewasa ini, performa pemain bulutangkis India mengalami penurunan dan itu semua terbukti dengan banyaknya kekalahan-kekalahan pemain India di turnamen internasional. Adhiyasa (2019) menyatakan bahwa pencapaian prestasi bulutangkis, misalnya Pusarla Venkata Sindhu tidak tidak stabil usai merebut gelar juara dunia 2019. Bintang tunggal putri India itu disebut-sebut tengah mengalami "post champions sindrome" setelah sebelumnya kerap gagal di sejumlah partai final. Keberhasilan Sindhu merebut tahta juara dunia 2019 di Basel, Swiss pada Agustus lalu merupakan titik puncak dari torehan prestasi sebelumnya yang selalu anti klimaks. Konsekuensinya pemain bulutangkis dituntut untuk meningkatkan dan mengoptimalkan performanya. Dari paparan tersebut, dapat disimpulkan bahwa bulu tangkis dapat meningkatkan kebugaran dan rasa sosial, hiburan serta mental. Kebugaran tercipta jika komponen fisiknya bagus. Komponen fisik akan bagus jika terlatih melakukan aktivitas fisik yang mendukung. Dengan demikian, secara tidak langsung permainan bulu tangkis dapat meningkatkan komponen fisik pemainnya. Salah satunya adalah kelincahan.

Menurut Harsono (1988), kelincahan sangat penting untuk dimiliki oleh setiap orang dalam kehidupan sehari-hari. Apalagi dalam kegiatan olahraga, kelincahan sangat diperlukan, baik dalam cabang olahraga permainan seperti bulutangkis. Faktor-faktor yang mempengaruhi kelincahan yaitu: kekuatan, kecepatan, kecepatan reaksi (waktu reaksi), keseimbangan, neuromuscular, dan koordinasi faktor-faktor tersebut. Karena pentingnya kelincahan untuk kelangsungan hidup sehari-hari apalagi untuk seorang atlet, Harsono (1988) menyatakan bahwa dalam melakukan aktivitas tersebut dia juga tidak boleh kehilangan keseimbangan dan harus pula sadar akan posisi tubuhnya. Manuver-manuver demikian sering diperlukan dalam banyak cabang olahraga, terutama dalam cabang-cabang olahraga permainan seperti bulutangkis, olahraga perorangan pun memegang peranan yang sangat penting, oleh karena itu atletatlet cabang olahraga permainan seperti bulutangkis, agilitas memegang peranan yang sangat penting. Oleh karena itu atlet cabang olahraga tersebut harus dilatih untuk semakin mengembangkan agilitasnya. Salah satu latihan yang harus dikuasai di bulutangkis yaitu latihan shadow.

Latihan shadow atau latihan bayangan dilakukan dengan gerakan seperti sungguhan artinya pelaku melakukan gerakan seperti dia sedang bermain bulutangkis dia bergerak ke kiri depan, kanan, belakang seperti mengejar bola dan melakukan pukulan baik dengan raket maupun tanpa raket dengan teknik yang di instruksikan oleh pelatih. Selama melakukan latihan shadow atlet/sampel harus membayangkan arah shuttlecock datang dan membayangkan shuttlecock pengembalian kita, untuk itu tahap pemula latihan shadow, biasanya atlet bergerak ke berbagai arah dengan instruksi dari pelatih. Setelah atlet dianggap menguasai apa yang harus diistruksikan pelatih atlet diberikan kebebasan untuk bergerak sesuai dengan daya tafsir dari atlet itu sendiri. Untuk memberikan dampak yang besar terhadap performa atlet, latihan harus diimbangi dengan kedisiplinan.

Disiplin mempunyai makna yang luas dan berbeda-beda, oleh karena itu disiplin mempunyai berbagai macam pengertian. istilah disiplin berasal dari bahasa latin "Disiplina" yang menunjuk kepada kegiatan belajar dan mengajar. Istilah tersebut sangat dekat dengan istilah dalam bahasa Inggris "Disciple" yang berarti mengikuti orang untuk belajar di bawah pengawasan seorang pemimpin (Tu'u, 2004). Pengertian tentang disiplin telah banyak didefinisikan dalam berbagai versi oleh para ahli. Ahli yang satu mempunyai batasan lain apabila dibandingkan dengan ahli lainnya. Definisi pertama yang berhubungan dengan disiplin diantaranya seperti yang dikemukakan oleh Hoedaya (2007) yaitu kepatuhan untuk menghormati dan melaksanakan suatu sistem yang mengharuskan orang untuk tunduk pada keputusan, perintah atau peraturan yang berlaku. Dengan kata lain, disiplin adalah kepatuhan mentaati peraturan dan ketentuan yang telah ditetapkan, sedangkan Khalsa (2008) menjelaskan bahwa disiplin melatih melalui pengajaran dan pelatihan. Menurut Koesoema (2007), istilah disiplin terutama mengacu pada proses pembelajaran. Disiplin senantiasa dikaitkan dengan konteks relasi antara murid dan guru serta lingkungan yang menyertainya, seperti tata peraturan, tujuan pembelajaran dan pengembangan kemampuan dari murid melalui bimbingan guru. Sementara Njoroge dan Nyabuto (2014) menyatakan 
bahwa disiplin adalah unsur yang sangat penting bagi keberhasilan prestasi akademik siswa. Disiplin sekolah memainkan peran penting dalam pencapaian harapan dan tujuan pembelajaran. Hal ini juga memainkan peran penting dalam akuisisi rasa tanggung jawab pada peserta didik serta pendidik. Dalam bahasa Indonesia, istilah disiplin sering terkait dan menyatu dengan istilah tata tertib dan ketertiban. Istilah ketertiban mempunyai arti kepatuhan seorang dalam mengikuti peraturan atau tata tertib karena dorongan atau disebabkan oleh sesuatu yang datang dari luar dirinya. Sebaliknya istilah disiplin sebagai kepatuhan dan ketaatan yang muncul karena adanya kesadaran dan dorongan dari dalam diri orang itu. Hal ini sesuai dengan pendapat Zuriah (2006) yang menyatakan bahwa seseorang dikatakan berdisiplin apabila melakukan pekerjaan dengan tertib dan teratur sesuai dengan waktu dan tempatnya serta dikerjakan dengan penuh kesadaran, ketekunan, keikhlasan atau tanpa paksaan dari pihak manapun. Berdasarkan uraian tersebut, dapat disimpulkan bahwa disiplin adalah suatu kepatuhan atau ketaatan seseorang terhadap peraturan dan tata tertib yang telah ditetapkan berdasarkan dorongan dan kesadaran yang muncul dalam hatinya serta dilakukan secara teratur tanpa adanya paksaan atau tekanan dari pihak manapun.

Apapun bentuk kegiatan yang jika dilaksanankan secara kelembagaan, yang melibatkan sejumlah personal dan memamfaatkan sumber daya, maka unsur manajemen memegang peranan penting. Kata kunci disini adalah manajemen dibutuhkan karena kita selalu berhadapan dengan tantangan berupa kelangkaan sumber daya. Tidak ada sumber daya yang berlebihan, lebih-lebih untuk kondisi penjas dan olahraga di Indonesia seperti kondisi sekarang ini. Fungsi utama manajemen adalah untuk mengoptimalkan efisiensi, sekaligus efektivitas pembinaan. Kedua istilah ini terkait langsung dengan sasaran dan tujuan pembinaan. Sangat besar peluang bahwa pembinaan itu berlangsung dalam keadaan efisiensi yang amat rendah jika bukan sebagai pemborosan. Dalam konteks Manajemen olahraga adalah suatu kombinasi ketrampilan yang berhubungan dengan perencanaan, pengorganisasian, kepemimpinan, pengendalian, penganggaran, dan evaluasi dalam kontek suatu organisasi yang memiliki produk utama berkaitan dengan olahraga. Park (1998) pengkobinasian tersebut perlu sumber daya manusia yang terlibat dalam organisasi, bersatu dalam sebuah system bahu membahu bekerja untuk mencapai tujuan.

\section{METODE}

Jenis penelitian ini adalah deskriptif kualitatif. Metode deskriptif didefinisikan sebagai metode sebuah metode penelitian yang dimaksudkan untuk mendeskripsikan peristiwa-peristiwa yang ada yang masih terjadi sampai saat sekarang atau waktu yang lalu (Sukardi, 2008). Teknik pengumpulan data yang digunakan dalam penelitian ini adalah observasi lapangan.

Tempat penelitian yaitu di PB Wiratama Jaya Yogyakarta dan CSN Badminton Academy India. Waktu penelitian dilaksanakan selama peneliti melatih di tiap klub. Peneliti melakukan penelitian di $P B$ Wiratama Jaya Yogyakarta pada bulan September-Oktober 2019. Sedangkan, melakukan penelitian di CSN Badminton Academy Ottapalam India pada bulan November-Desember 2019 dengan PB. Wiratama Jaya Yogyakarta Indonesia.

Populasi dalam penelitian ini adalah atlet di CSN Badminton Academy Ottapalam India yang berjumlah adalah 32 atlet laki-laki dan atlet di PB Wiratama Jaya Yogyakarta Indonesia yang berjumlah 28 atlet. Instrumen yang akan digunakan pada penelitian ini yaitu human instrument atau yang dikenal sebagai peneliti adalah sumber maupun ahli/pakar sehingga dapat menentukan sendiri dan berperan menyusun dan menjadi instrumen itu sendiri khususnya dalam ranah kajian pendekatan kualititatif. Peneliti merupakan instrumen itu sendiri, dengan kata lain peneliti juga perlu "divalidasi" seberapa jauh peneliti kualitatif siap melakukan penelitian yang selanjutnya turun ke lapangan (Sugiyono, 2010). Adapun jenis data yang digunakan pada penelitian ini yaitu data sekunder dan data primer dari kedua klub. Sebelum terjun ke lapangan, peneliti sudah melakukan analisis terlebih dahulu menggunakan data sekunder yang dapat digunakan untuk fokus penelitian. Selama di lapangan, peneliti melakukan analisis data dengan menggunakan metode Miles et al. (2014). Peneliti akan melakukan beberapa kali wawancara sampai datanya jenuh kemudian melakukan reduksi data. Setelah mereduksi data, peneliti akan melakukan penyajian data dan terakhir melakukan kesimpulan (Sugiyono, 2010). 


\section{HASIL DAN PEMBAHASAN}

\section{Hasil}

Berdasarkan observasi lapangan langsung dalam penelitian ini dengan pengamatan yang dilakukan pada kedua klub (persatuan bulutangkis) yang ada di Indonesia yaitu PB. Wiratama Jaya Yogyakarta Indonesia dan klub (persatuan bulutangkis) yang ada di India yaitu CSN Badminton Academy Ottapalam India dapat di deskripsikan secara gamblang pada Tabel 1.

Tabel 1. Deskripsi perbandingan pola manajemen pelatihan secara umum

\begin{tabular}{ccll}
\hline No & \multicolumn{1}{c}{ Jenis } & \multicolumn{1}{c}{ Yogyakarta Indonesia } & \multicolumn{1}{c}{ Ottapalam India } \\
\hline 1. & $\begin{array}{l}\text { Latihan } \\
\text { Shadow }\end{array}$ & $\begin{array}{l}\text { Menggunakan langkah sehingga } \\
\text { pergerakan footwork cenderung lebih } \\
\text { efisien. }\end{array}$ & $\begin{array}{l}\text { Menggunakan lompat sehingga pergerakan } \\
\text { footwork cenderung kurang efisien. }\end{array}$ \\
2. & Kedisiplinan & $\begin{array}{l}\text { Atlet lebih disiplin terhadap waktu dan } \\
\text { peraturan pelatihan } \\
\text { struktur manajemen organisasi cenderung } \\
\text { masih kurang tertata. }\end{array}$ & $\begin{array}{l}\text { Masih ada atlet yang tidak disiplin waktu } \\
\text { dan peraturan pelatihan } \\
\text { Struktur manajemen organisasi lebih } \\
\text { tertata. }\end{array}$ \\
3. & Manajemen &
\end{tabular}

\section{Deskripsi Kondisi di PB. Wiratama Jaya Yogyakarta Indonesia}

Berikut deskripsi per jenis pengamatan yang peneliti lakukan terkait perbandingan pola manajemen pelatihan dalam perspektif pengamatan di PB. Wiratama Jaya Yogyakarta Indonesia.

\section{Latihan Shadow}

Selain teknik dasar pukulan bulutangkis, seorang pemain juga wajib menguasai latihan shadow dalam bulutangkis. Dimana latihan shadow ini sangat bermanfaat dan dapat meningkatkan efektivitas dan efisien pergerakan atlet atau pemain bulutangkis. Latihan shadow ini mempunyai tujuan untuk melatih pergerakan kaki guna menjelajah serta menguasai lapangan bulutangkis.

Adapun latihan shadow yang diberikan oleh pelatih-pelatih yang ada di PB. Wiratama Jaya Yogyakarta Indonesia sedikit berbeda dengan latihan shadow yang dilakukan di India. Adapun latihan shadow yang dilakukan di PB. Wiratama Jaya Yogyakarta Indonesia sebagai berikut. Atlet memulai posisi di tengah lapangan, lalu melangkahkan kaki ke pojok kanan depan, lalu kembali ke tengah dengan langkah mundur jingkat kaki kanan dan kiri secara bergantian. Selanjutnya melangkah ke kiri depan dan kembali lagi ke posisi tengah dengan langkah yang sama. Setelah itu, kembali ke tengah dengan langkah mundur jingkat. Langkah mundur dengan mengjingkatkan tungkai lebih efesien karena pemain bisa lebih cepat kembali ke posisi awal. Selain itu, atlet bisa lebih siap untuk menerima shuttlecock dari lawan dan tidak mengeluarkan banyak energi. Langkah seperti ini di gunakan para pemain international di era sekarang.

\section{Disiplin}

Dari data sekunder yang diberikan oleh pelatih, kedisiplinan atlet di PB. Wiratama Jaya Yogyakarta Indonesia terbilang cukup baik. Hampir setiap atlet datang ke tempat latihan sebelum jam latihan dimulai. Hampir semua atlet berdomisili di Kota Yogyakarta, sehingga memudahkan akses menuju tempat latihan. Selain itu, atlet di PB. Wiratama Jaya Yogyakarta Indonesiasangat menaati peraturan yang dibuat oleh pelatih selama latihan maupun peraturan yang dibuat oleh klub. Hal ini disebabkan oleh daya saing yang cukup tinggi antar atlet. Saat ada pertandingan, tidak semua atlet PB. Wiratama Jaya Yogyakarta Indonesia bermain pada pertandingan tersebut. Pelatih akan menseleksi siapa yang akan bertanding pada pertandingan tersebut. Oleh karena itu, tiap atlet sangat menaati peraturan yang diberikan oleh pelatih maupun klub agar tetap diikutkan dalam pertandingan-pertandingan yang akan datang.

\section{Manajemen Organisasi}

PB. Wiratama Jaya Yogyakarta Indonesiaberdiri sejak 2013 akhir dan sudah memiliki struktur organisasi pengurus yang cukup jelas. PB. Wiratama Jaya Yogyakarta Indonesiasudah punya pelindung yaitu PBSI cabang Kota Yogyakarta. Secara administrasi, PB. Wiratama Jaya Yogyakarta Indonesia memiliki dua ketua, satu sekretaris, satu bendahara, dan empat pelatih. Adapun atlet yang saat ini tercatat sebagai atlet binaan PB. Wiratama Jaya Yogyakarta Indonesia sebanyak 28 atlet. Usia atlet binaan PB. 
Wiratama Jaya Yogyakarta Indonesia cukup beragam yaitu, mulai dari usia 9 tahun sampai 17 tahun keatas.

Walaupun struktur pengurus klub PB. Wiratama Jaya Yogyakarta Indonesia sudah cukup jelas dengan adanya pelindung, ketua, sekretaris dan pelatih, akan tetapi bukti secara administrasi belum lengkap. Adapun bukti fisik yang belum dimiliki oleh PB. Wiratama Jaya Yogyakarta Indonesia yaitu, kantor pengurus, papan nama pengurus, daftar perlengkapan yang dimiliki, dan data kehadiran atlet.

Suatu klub olahraga tidak dapat berjalan dengan baik apabila tidak memiliki dana operasional. Dana operasional di PB. Wiratama Jaya Yogyakarta Indonesia berasal dari peserta latih dengan biaya Rp. 200.000,00 perbulan. Sejauh ini, tidak banyak sponsor yang bekerjasama dengan PB. Wiratama Jaya Yogyakarta. Hal tersebut dikarenakan klub yang baru berjalan beberapa tahun.

Adapun fasilitas yang disediakan oleh PB. Wiratama Jaya Yogyakarta Indonesia sudah cukup baik. PB. Wiratama Jaya Yogyakarta Indonesia biasa melakukan latihan rutin di GOR Segoro Amarto dan GOR BLPTK Yogyakarta. PB. Wiratama Jaya Yogyakarta Indonesia juga memiliki alat latihan yang disediakan untuk atlet berupa net, shuttlecock, raket, dan baju latihan.

\section{Deskripsi Kondisi di CSN Badminton Academy Ottapalam India}

Berikut deskripsi per jenis pengamatan yang peneliti lakukan terkait perbandingan pola manajemen pelatihan dalam perspektif pengamatan di CSN Badminton Academy Ottapalam India.

\section{Latihan Shadow}

Selain teknik dasar pukulan bulutangkis, seorang pemain juga wajib menguasai teknik dasar footwork atau shadow badminton. Dimana teknik footwork ini sangat bermanfaat dan dapat meningkatkan efektivitas dan efisien pergerakan atlet atau pemain bulutangkis.

Pada dasarnya latihan shadow di CSN Badminton Academy Ottapalam India tidak jauh berbeda dengan PB. Wiratama Jaya Yogyakarta, namun terdapat sedikit perbedaan khususnya pada saat pergerakan atlet kembali ke center line. Atlet memulai posisinya dari tengah lapangan. Lalu kembali ke posisi tengah dengan melompatkan tungkai kanan dan tungkai kiri ke belakang secara bergantian. Atlet kembali pada posisi awal dalam keadaan posisi tungkai kanan di depan dan posisi tungkai kiri di belakang. Latihan shadow dengan cara melompat saat ke posisi awal merupakan cara yang kurang efisien. Hal tersebut dikarenakan atlet akan lebih lama untuk bereaksi ke posisi selanjutnya. Atlet harus meredam lompatan yang ia lakukan dengan menggunakan teknik pegas pada kedua tungkai dan setelah itu baru melanjutkan ke posisi selanjutnya. Walaupun begitu, latihan shadow seperti yang dilakukan di CSN Badminton Academy Ottapalam India pernah diterapkan di era Rudi Hartono.

Disiplin

Selama peneliti melatih di CSN Badminton Academy India, peneliti menemukan beberapa isu terkait kedisiplinan atlet. Setelah melakukan wawancara dengan ketua dan pelatih yang lain, peneliti mendapati bahwa jarak antara rumah atlet dengan tempat latihan cukup jauh. Tiap atlet harus menempuh waktu satu sampai dua jam untuk ke tempat latihan. Hal ini yang menyebabkan sebagian besar atlet sering datang terlambat. Selain itu, atlet juga cukup sulit untuk berkonsetrasi terhadap latihan yang diberikan oleh pelatih karena energi yang sudah terkuras selama seharian belajar di sekolah dan melakukan perjalanan jauh menuju tempat latihan.

Manajemen Organisasi

CSN Badminton Academy Ottapalam India berdiri pada tahun 2013 dan dibawahi langsung oleh KBA (Kerala Badminton Association). Adapun susunan pengurus CSN Badminton Academy Ottapalam India tediri dari satu ketua, dua bendahara, dua sekretaris, tiga pelatih. CSN Badminton Academy Ottapalam India memiliki 32 atlet binaan yang terdiri dari usia 9 tahun sampai 15 tahun keatas.

Secara administrasi, CSN Badminton Academy Ottapalam India juga memiliki bukti fisik yaitu, kantor kepengurusan klub, papan nama kepengurusan klub, data presensi atlet yang hadir tiap latihan dan daftar perlengkapan yang dimiliki. Selain itu, CSN Badminton Academy Ottapalam India juga memiliki buku jurnal yang diisi oleh pelatih dan didalamnya terdiri dari progres yang sudah dilakukan tiap atlet. Hal ini memudahkan pelatih jika sewaktu-waktu orang tua atlet bertanya tentang progres yang dilakukan oleh anaknya selama berlatih di CSN Badminton Academy Ottapalam India. 
Sumber dana yang dimiliki oleh CSN Badminton Academy Ottapalam India berasal dari iuran peserta latih dan Office CSN Cultural Trust, CSN Cultural Trust yaitu Auditorium Sri Chettur Sankaran Nair memorial. Selain itu, CSN Badminton Academy Ottapalam India memiliki kerjasama dengan beberapa sponsor dibidang olahraga maupun minuman isotonik. Sehingga saat ada pertandingan, sponsor tersebut dapat memberikan barang atau alat maupun fresh money untuk menunjang biaya pertandingan.

Adapun fasilitas latihan yang disediakan CSN Badminton Academy Ottapalam India berupa hall badminton, gym, baju latihan dan alat-alat latihan (net, shuttlecock, cone, raket dan plyometric box).

\section{Pembahasan}

Menurut dari deskripsi pada hasil penelitian tersebut, patutlah para pelaku olahraga di lapangan khususnya olahraga prestasi untuk dapat selalu memantau perkembangan dan keterbaharuan ilmu pengetahuan dan teknologi khususnya disiplin ilmu keolahragaan yang mana sangat penting untuk pengoptimalan kinerja olahraga. Dalam kapasitas ini, ilmu keolahragaan akan melibatkan interaksi yang erat antara ilmuan keolahragaan dan arah pengembangan serta pelaksanaan intervensi pelatihan yang dijalani atlet dalam upaya mengoptimalkan kinerja olahraga di semua tingkatan (Stone et al., 2004).

Konsep dan Prinsip Latihan

Pada analisis (studi kualitatif) ini dimana mencoba mengkomparasikan antara bagaimana cara melatihkan shadow badminton antara PB. Terkait dengan bentuk latihan shadow badminton, Rahman dan Warni (2017) menuturkan bahwasanya gambaran bentuk latihan dalam shadow badminton layaknya bermain bulutangkis yang benar. Kita harus menguasai dasar dari teknik pukulan (stroke) dan langkah kaki, teknik pukulan yg benar bagi pebulutangkis tangan kanan adalah pada posisi mau memukul maka posisi kaki kanan harus di belakang kaki kiri kemudian tangan ditarik ke belakang siap dengan posisi memukul. Posisi pukul yg optimal adalah pada saat bola berada kurang lebih 10 derajat di atas depan posisi kita, pengambilan posisi ini erat kaitannya dengan pergerakan kaki untuk mencari posisi yang optimal, latihan untuk melakukan pukulan yang baik adalah dengan cara melatih lob dengan patner kita selama mungkin, sementara untuk langkah kaki, kita bisa melakukan latihan shadow badminton (pergerakan langkah kaki dengan tanpa shuttlecock). Wiratama Jaya Yogyakarta Indonesia dengan CSN Badminton Academy Ottapalam India ditemukan sedikit hal perbedaan dimana perbedaan tersebut sejatinya tidak terlalu berlebihan, namun dapat berakibat cukup fatal bagi kinerja atlet pada saat melakukan pergerakan pada saat bermain atau bertanding dimana pergerakan footwork dari atlet menjadi tidak efisien khususnya dalam bereaksi mengubah posisi dalam waktu yang cepat.

Penguasaan kemampuan koordinasi untuk mewujudkan ketrampilan gerak pada cabang olahraga, hanya dapat dicapai melalui proses pembelajaran dan pelatihan, yaitu mempelajari dan memahami polapola latihan, yang selanjutnya harus diikuti dengan latihan, yaitu dengan mengulang (drilling) gerakan yang harus dikuasai tersebut. Tujuan pengulangan adalah agar atlet menjadi hafal bagaimana melakukan koordinasi gerakan itu secara akurat. Hal ini senada dengan pernyatan yang diutarakan oleh (Kusuma, 2013) bahwasanya pelatihan merupakan suatu proses berlatih yang sistematis yang dilakukan secara berulang-ulang dan jumlah beban pelatihannya bertambah. Sehingga memberikan rangsangan secara menyeluruh terhadap tubuh dan bertujuan untuk meningkatkan kemampuan fisik dan mental secara menyeluruh.

Dalam konteks fisiologi, drilling dimaksudkan agar penguasaan gerakan tersebut mencapai tingkat reflek bersyarat (conditionet reflect). Mutu tinggi ketrampilan gerak kecabangan olahraga diwujudkan oleh akurasi tinggi gerakan tersebut. Akurasi gerak dalam hal ini merupakan wujud dari akurasi koordinasi fungsi komponen-komponen neoromuscular yang terlibat dalam gerakan tersebut. Kemampuan mewujudkan gerak yang akurat hakikatnya adalah kemampuaan mewujutkan keindahan gerak. Semua cabang olahraga prestasi menuntut tercapainnya akurasi gerakan (Giriwijoyo \& Sidik, 2019). Hal senada juga lebih dipertegas kembali oleh Iaia et al. (2011) yang menyatakan bahwa sejumlah studi cross-sectional telah meneliti masalah faktor fisiologis mana yang menentukan kinerja atau apa yang menyebabkan kelelahan pada berbagai intensitas latihan. Sehingga dapat dinyatakan dan dipertegas banyak faktor secara fisiologis yang nantinya akan memberikan pengaruh besar terhadap kualitas penampilan atlet di lapangan.

Berkaitan dengan hal tersebut dapat disimpulkan bahwa perlunya kembali tim pelatih mencermati lebih mendalam terkait konsep dasar pelatihan teknik bulutangkis secara hakiki dan penyesuaian dalam langkah-langkah proses pelatihan dimana dengan tetap mengindahkan prinsip-prinsip latihan yang ber- 
laku. Hal ini dapat dijadikan pencermatan dimana sesuai dengan pernyataan dari Halson dan Jeukendrup (2004) bahwasanya program pelatihan dirancang untuk meningkatkan kinerja dengan mengembangkan sumber energi yang sesuai, meningkatkan struktur otot, dan meningkatkan pola keterampilan otot saraf. Ahli kedokteran olahraga harus memahami prinsip dasar dan proses pelatihan, sehingga mereka dapat mengevaluasi program pelatihan dan menentukan kecukupannya dalam menjaga kesehatan atlet dan mencegah cedera. Sebagai referensi bahan pencermatan, dapat dimaknai berdasarkan teori yang disampaikan oleh Sukadiyanto dan Muluk (2011), pada beberapa prinsip yang dapat dilaksanakan sebagai pedoman agar tujuan latihan tercapai yaitu.

\section{Prinsip Kesiapan}

Pada prinsip ini, materi dan dosis latihan harus disesuaikan dengan usia, karena hal ini berkaitan dengan kondisi fisiologis dan psikologis olahragawan. Hal tersebut berarti bahwa para pelatih harus mempertimbangkan dan memperhatikan tahap pertumbuhan dan perkembangan atletnya.

\section{Prinsip Individual}

Prinsip ini berdasar dari perbedaan individu setiap orang dan tidak dapat disamakan antara orang yang satu dengan yang lainnya. Beberapa faktor yang dapat membedakan antara lain: faktor keturunan, faktor kematangan, faktor gizi, faktor waktu istirahat dan tidur, faktor kebugaran, lingkungan, sakit, cedera, and motivasi.

\section{Prinsip adaptasi}

Pada prinsip ini organ tubuh manusia cenderung selalu mampu untuk beradaptasi terhadap perubahan lingkunganya. Keadaan ini tentu menguntungkan untuk keterlaksanaan proses berlatih-malatih sehingga kemampuan manusia dapat dipengaruhi dan ditingkatkan melalui proses latihan.

\section{Prinsip beban lebih}

Prinsip ini berbicara tentang beban latihan harus mencapai atau melampaui sedikit diambang batas rangsangan. Sebab beban yang terlalu berat akan mengakibatkan tidak mampu diadaptasi oleh tubuh, sedang bila terlalu ringan tidak berpengaruh terhadap peningktan kualitas fisik, sehingga beban latihan harus memenuhi prinsip latihan itu.

\section{Prinsip progresif}

Agar terjadi proses adaptasi pada tubuh, maka diperlukan prinsip beban lebih yang diikuti dengan prinsip progresif. Latihan yang bersifat progresif artinya dalam pelaksanaan latihan dilakukan dari yang mudah ke yang sukar, sederhana ke kompleks, umum ke khusus, bagian ke keseluruhan, ringan ke berat, dan dari kuantitas ke kualitas.

\section{Prinsip spesifik}

Untuk prinsip spesifik ini materi latihan harus dipilih sesuai dengan kebutuhan cabang olahraganya. Untuk itu, sebagai pertimbangan dalam menerapkan prinsip spesifikasi antara lain di tentukan oleh: (a) spesifikasi kebutuhan energy, (b) spesifikasi bentuk dan metode latihan, (c) spesifikasi ciri gerak dan kelompok otot yang digunakan, (d) waktu periodisasi latihan.

\section{Prinsip variasi}

Program latihan yang baik harus disusun secara variatif untuk menghindari kejenuhan keengganan dan keresahan yang merupakan kelelahan secara psikologis. Untuk itu program latihan perlu disusun lebih variatif agar tetap meningkatkan ketertarikan olahrgawan terhadap latihan, sehingga tujuan latihan tercapai.

\section{Prinsip pemanasan dan pendinginan}

Dalam satu unit latihan atau satu pertemuan latihan selalu terdiri dari: (1) pengantar (2) pemanasan (3) latihan inti, (4) latihan suplemen (5) cooling down. Pemanasan bertujuan untuk mempersiapkan fisik dan psikis olahragawan memasuki latihan inti sedangkan tujuan pendinginan adalah agar tubuh kembali pada keadaan normal secara bertahap dan tidak mendadak setelah latihan.

\section{Prinsip latihan jangka panjang}


Untuk meraih prestasi terbaik, diperlukan proses latihan dalam jangka waktu yang lama, pengaruh beban latihan tidak dapat diadaptasi oleh tubuh secara mendadak tetapi membutuhkan waktu dan proses yang harus dilakukan secara bertahap dan kontinyu.

\section{Prinsip berkebalikan}

Prinsip ini berarti olahragawan berhenti dari latihan dalam waktu tertentu bukan dalam waktu yang lama, maka kualitas organ tubuh akan mengalami penurunan fungsi secara otomatis.

\section{Prinsip tidak berlebihan}

Prinsip ini menekankan bahwa pembebanan harus disesuaikan dengan tingkat kemampuan, pertumbuhan, dan perkembangan olahragawan sehingga beban latihan yang diberikan benar-benar tepat.

\section{Prinsip sistematik}

Prinsip ini berkaitan dengan ukuran atau dosis pembebanan dan skala prioritas, sasaran latihan, setiap sasaran latihan memiliki aturan dosis pembebanan yang berbeda-beda.

Kedisiplinan

Pada analisis (studi kualitatif) ini dimana mencoba mengkomparasikan antara bagaimana cara pola kedisiplinan maupun terhadap ketaataturan terhadap peraturan yang berlaku saat proses pelatihan antara PB. Wiratama Jaya Yogyakarta Indonesia dengan CSN Badminton Academy Ottapalam India ditemukan sedikit hal perbedaan dimana perbedaan tersebut sejatinya tidak terlalu berlebihan, namun dapat berakibat cukup fatal bagi kinerja atlet pada saat melakukan aktivitas pelatihan.

Sekalipun hal tersebut bukanlah bersifat pemakluman, namun sejatinya khusus pada para atlet dari CSN Badminton Academy Ottapalam India kekurang disiplinan tersebut terjadi mengingat kendala jarak tempat latihan dari rumah masing-masing. Pada sisi lain dapat diketahui bahwasanya memang di India cabang olahraga bulutangkis belum menjadi salah satu yang di unggulkan layaknya di Indonesia, sehingga daya dukungnya belum selaik di Indonesia.

Namun terlepas dari beberapa hal tersebut, ada baiknya bila kita semua dapat mencermati hal-hal yang bijak terkait kedisiplinan tersebut dari berbagai narasumber. Menurut Setyobroto (2002) dalam kehidupan sosial merupakan kehidupan yang penuh dengan nilai-nilai. Orang yang memiliki sifat disiplin terlihat dari kesediaan untuk mereaksi dan bertindak terhadap nilai-nilai yang berlaku, yaitu nilainilai yang tertuang dalam bentuk: ketentuan, tata tertib, aturan, tatanan hidup, atau kaidah kaidah tertetu.

Jadi disiplin dalam bidang latihan ini harus dimiliki oleh setiap atlet yang bertujuan untuk mencapai prestasi maksimal, dan disiplin tersebut dapat itingakatkan menjadi disiplin diri, dengan demikian dapat dikatakan seorang atlet yang memiliki tingkat disiplin diri yang tinggi maka setiap latihan yang dilakukan akan memproleh hasil yang maksimal maka dapat dikatakan atlet akan dapat meraih sebuah prestasi dalam biadang olahraga yang digelutinya. Begitu juga sebaliknya jika seorang atlet kurang memiliki disiplin diri dalam mengikuti latihan yang dilakukan maka seorang atlet tidak dapat mencapai hasil latihan yang maksimal sehingga menurunnya prestasi olahraga yang digelutinya.

Berlandasan pada teori sosial bahwa manusia merupakan makhluk sosial yang hidup di lingkungan. Lingkungan sosial sebagai tempat beraktivitas akan mempengaruhi pembentukan karakter manusia. Pembentukan karakter merupakan proses sepanjang kehidupan manusia. Sejalan dengan ungkapan tersebut bahwa kedisiplinan merupakan salah satu nilai yang akan dibentuk dimana disiplin melandasi proses berlatih disetiap latihan yang dilakukan, dalam hal ini disiplin dalam latihan dapat mengembangkan kualitas fisik, teknik, taktik dan mental sampai tingkatan maksimal pada saat latihan.

Kedisiplinan merupakan salah satu nilai yang terbentuk dari proses berlatih. Manusia akan memiliki tingkat kedisiplinan tinggi, yang akan ditransfer untuk melaksanakan aktivitas fisik yang dilakukannya. Berikut telaah terkait disiplin dari berbagai perpspektif yang dipaparkan oleh para pakar.

Peneliti berpandangan bahwasanya disiplin merupakan komponen penting dari perilaku manusia dan menegaskan bahwa tanpa itu suatu organisasi tidak dapat berfungsi dengan baik menuju pencapaian tujuannya, merujuk dari pernyataan Ouma et al. (2013). Terkait dengan pola pandang disiplin dalam peningkatan performa, pernyataan dari Gitome et al. (2013) dapat menjadi rujukan sebagai penguat atas hubungan yang sangat erat antara factor disiplin terhadap kualitas performa atlet dimana terdapat disiplin yang baik, maka prestasi akan meningkat. Sehingga pada sudut pandang yang lain, maka akan terjadi pola pandang yang umumnya sebagai bentuk yang berlawanan terkait dengan kedisiplinan, dimana 
terdsapat pihak yang disiplin, umumnya akan terdapat pula pihak tertentu yang kecenderungannya dapat dikatakan kurang bahkan cenderung tidak disiplin. Hal ini menurut Omote et al. (2015) sebagai gambaran dari bentuk ketidakdisiplinan dapat dilihat sebagai tindakan yang dianggap salah dan tidak secara umum diterima sebagaimana mestinya dalam tatanan atau masyarakat, sehingga dapat dinyatakan apabila merujuk pada pernyataan tersebut maka secara tidak langsung selain mereka yang cenderung tidak disiplin atau kurang disiplin tersebut tidak hanya akan berdampak pada kualitas performanya saja, melainkan juga secara moral dari lingkungn sekitarnya yang dalam hal ini dapat dikatakan dari lingkungan berlatih bulu tangkisnya dalam komunitasnya tersebut.

Hal ini pula berkesinambungan antara cakupan perpspektif disiplin terhadap kualitas performa yang langsung terfokus pada unsure fisiologis bahkan unsure pendukung lainnya. Penguatan tersebut diungkapkan oleh Čoh (2003); dan Goodway et al. (2003) bahwa kesuksesan dalam disiplin atletik tertentu bergantung pada keterampilan motorik yang menjadi dasarnya sukses dalam aktivitas tertentu, tentunya dengan partisipasi struktur lain (morfologis, fungsional, konatif dan kognitif). Sukses dalam olahraga dan keterampilan motorik mencapai tingkat korelasi yang tinggi

menurut koefisien genetik.

\section{Manajemen Organisasi Olahraga}

Pada analisis (studi kualitatif) ini dimana mencoba mengkomparasikan antara bagaimana cara pola kedisiplinan maupun terhadap ketaat aturan terhadap peraturan yang berlaku saat proses pelatihan antara PB. Wiratama Jaya Yogyakarta Indonesia dengan CSN Badminton Academy Ottapalam India ditemukan sedikit hal perbedaan dimana perbedaan tersebut sejatinya tidak terlalu mencolok, dimana perbedaannya hanya terletak kepada beberapa hal yang sifatnya cenderung bersifat administratif.

Kecenderungan hal-hal sederhana layaknya papan nama Klub bulutangkis, historical klub bulutangkis, biografi para pengurus klub bulutangkis yang dipasang di tempat latihan, jurnal-jurnal terkait pelatihan bulutangkis hingga presensi latihan permanen. Namun justru beberapa hal tersebut merupakan salah satu identitas dari klub bulutangkis tersebut yang memang harus diakui di berbagai tempat di Indonesia belum banyak yang memunculkan dan mengeterapkannya.

Sebelum secara spesifik kajian difokuskan kepada analisa seputar manajemen organisasi terkait dunia olahraga, ada baiknya untuk dapat menjadi pencermatan dan telaah di awal perlunya dapat memaknai terlebih dahulu apa itu olahraga. Menurut Proios et al. (2013) mengemukakan bahwa olahraga adalah bagian dari lingkungan sosial yang lebih besar, dan area di mana sebagian besar masyarakat secara aktif berpartisipasi sebagai atlet, wasit, pelatih, pemain, suporter, fans, dan lain-lain. Pada saat yang sama, olahraga adalah salah satunya faktor yang mendorong perkembangan budaya manusia. Merunut dari pemaknaan olahraga tersebut dapat disimpulkan bahwa sesungguhnya para pelaku olahraga secara otomatis merupakan bagian dari suatu organisasi dengan banyak orang dalam posisi, kepentingan dan targetnya masing-masing. Sehingga dalam perpspektif ini kiranya sekumpulan orang tersebut maka perlu untuk dikelola atau di manajemen agar dapat terkondisikan dengan jauh lebih baik.

Menurut Kautsar et al. (2018) manajemen sangat penting bagi setiap aktivitas individu atau kelompok dalam organisasi untuk mencapai tujuan yang diinginkan. Manajemen berorientasi pada proses yang berarti bahwa manajemen membutuhkan sumber daya manusia, pengetahuan dan keterampilan agar aktivitas lebih efektif atau dapat menghasilkan tindakan dalam mencapai kesuksesan. Oleh sebab itu, tidak akan ada organisasi yang akan sukses apabila tidak menggunakan manajemen yang baik.

Manajemen secara umum di definisikan sebagai kemampuan atau keterampilan untuk memeroleh suatu hasil dalam rangka pencapaian tujuan melalui kegiatan-kegiatan orang lain (Siagian, 2005). Manajemen dan administrasi tidak menjalankan sendiri-sendiri kegiatannya yang bersifat organisasional, tetapi bersama-sama berada dalam satu gerak dan langkah. Paturusi (2012) menegaskan pada proses administrasi fungsi-fungsi lebih bersifat general dan berlaku bagi seluruh organisasi. Sedangkan pada proses manajemen fungsi-fungsi lebih bersifat departemental atau sektoral. Fungsi adalah kegiatan atau tugas-tugas yang harus dikerjakan dalam usaha mencapai tujuan.

Dilihat adanya beberapa aspek utama masalah manajemen yaitu perencanaan (planning), pengorganisasian (organizing), pelaksanaan (actuating), dan pengawasan, monitoring dan evaluasi. Keempat fungsi tersebut akan dijelaskan sebagai berikut. 


\section{Manajemen Perencanaan}

Perencanaan adalah penentuan lebih awal tujuan yang ingin dicapai dan alat-alat yang digunakan untuk mencapai tujuan itu (Husdarta, 2011). Perencanaan itu mencakup apa yang dilakukan, bagaimana melakukan, dan siapa yang akan melakukannya. Karena selalu ada anggapan antara apa yang telah dicapai dan apa yang dituju, maka evaluasi dibutuhkan.

Manajemen Pengorganisasian

Menurut Harsuki (2012) mengartikan organisasi merupakan suatu arena dimana manusia bekerjasama guna melaksanakan tugas yang kompleks untuk mencapai tujuannya. Jadi, pengertian organisasi lebih berfokus pada upaya untuk mengaktualkan dan mengkoordinasikan kerjasama antara individu untuk mencapai tujuan yang telah ditetapkan.

\section{Manajemen Penggerakan}

Pergerakan dapat didefinisikan sebagai keseluruhan usaha, cara, teknik, dan metode untuk mendorong para anggota organisasi agar mau dan ikhlas bekerja dengan sebaik mungkin demi tercapainya tujuan organisasi dengan efisien, efektif dan ekonomis.

Manajemen pengawasan monitoring dan evaluasi

Menurut Mesnan dan Antonius (2019) pengawasan dapat diartikan sebagai suatu proses untuk menerapkan pekerjaan apa yang sudah dilaksanakan, menilainya, dan bila perlu mengoreksi dengan maksud supaya pelaksanaan pekerjaan sesuai dengan rencana semula. Dalam melaksanakan kegiatan controlling, seorang pemimpin mengadakan pemeriksaan serta mengusahakan agar kegiatan-kegiatan yang dilaksanakan sesuai rencana yang telah ditetapkan serta tujuan yang ingin dicapai.

\section{SIMPULAN}

Berdasarkan hasil analisis data, deskripsi, pengujian hasil penelitian, dan pembahasan, dapat diambil kesimpulan, yaitu: Pertama, PB. Wiratama Jaya Yogyakarta Indonesia dan CSN Badminton Academy Ottapalam India memiliki jenis latihan shadow yang sedikit berbeda. CSN Badminton Academy Ottapalam India menggunakan teknik lompatan saat kembali ke posisi awal. Sedangkan PB. Wiratama Jaya Yogyakarta Indonesia tidak menggunakan teknik lompatan. Kedua, PB. Wiratama Jaya Yogyakarta Indonesia memiliki atlet yang patuh terhadap peraturan karena persaingan yang ketat. Sedangkan CSN Badminton Academy Ottapalam India memiliki atlet yang kurang patuh terhadap jam berlatih yang disebabkan jauhnya tempat latihan. Ketiga, CSN Badminton Academy Ottapalam India memiliki susunan kepengurusan yang baik serta memiliki bukti fisik. Sedangkan PB. Wiratama Jaya Yogyakarta Indonesia kurang melengkapi bukti fisik kepengurusan. Keempat, Dari keseluruhan analisa dan kajian secara akademik dari penelitian ini baik dalam perspektif optimalisasi prinsip latihan, optimalisasi kedisiplinan baik dari atlet hingga pelatih, manajemen organisasi, manajemen pengembangan dan peningkatan ilmu dan pengetahuan bagi para pelatih maupun pihak manajemen organisasi serta koordinasi dan komunikasi terhadap pihak orang tua agar terjalin hubungan dan interaksi social yang dapat saling mendukung dapat dijadikan rujukan yang sangat bermanfaat bagi PB. Wiratama Jaya Yogyakarta Indonesia maupun CSN Badminton Academy Ottapalam India dalam mengoptimalkan dari masing-masing kekurangan untuk dapat menjadi saling melengkapi agar dapat jadi lebih baik lagi. Dan kelima, Manusia sebagai subjek dan cabang olahraga sebagai objek merupakan bentuk variable yang sangat dinamis dimana setiap saat pasti akan terjadi perubahan dalam perkembangannya, sehingga wajib hukumnya bagi semua unsure terkait untuk dapat selalu cepat bereaksi agar dapat beradaptasi dan tidak ketinggalan terhadap segala bentuk perkembangan tersebut dan tidak terlepas pula bagi PB. Wiratama Jaya Yogyakarta Indonesia maupun CSN Badminton Academy Ottapalam India.

\section{DAFTAR PUSTAKA}

Adhiyasa, D. (2019). Ratu bulutangkis India ungkap pemicu jebloknya prestasi saat ini. Viva.Co.Id. https://www.viva.co.id/sport/raket/1187889-ratu-bulutangkis-india-ungkap-pemicu-jebloknyaprestasi-saat-ini

Čoh, M. (2003). Razvoj brzine u kondicijskoj pripremi sportaša. U D. Milanović i I. Jukić (Ur.), 
Kondicijska Priprema Sportaša, Zbornik Radova Međunarodnog Znanstveno-Stručnog Skupa, Zagreb, 21(22), 229-238.

Giriwijoyo, H. Y. S. S., \& Sidik, D. Z. (2019). Ilmu faal olahraga (fisiologi olahraga). Remaja Rosdakarya.

Gitome, J. W., Katola, M. T., \& Nyabwari, B. G. (2013). Correlation between students' discipline and performance in the Kenya Certificate of Secondary Education. International Journal of Education and Research, 1(8), 1-10. http://ir-library.ku.ac.ke/handle/123456789/13170

Goodway, J. D., Crowe, H., \& Ward, P. (2003). Effects of motor skill instruction on fundamental motor skill development. Adapted Physical Activity Quarterly, 20(3), 298-314. https://doi.org/10.1123/apaq.20.3.298

Grice, T. (1996). Bulu tangkis: Petunjuk praktis untuk pemula dan lanjut. PT RajaGrafindo Persada.

Halson, S. L., \& Jeukendrup, A. E. (2004). Does overtraining exist? Sports Medicine, 34(14), 967981. https://doi.org/10.2165/00007256-200434140-00003

Harsono, H. (1988). Coaching dan aspek-aspek psikologis dalam coaching. Direktorat Jendral Pendidikan Tinggi.

Harsuki, H. (2012). Pengantar manajemen olahraga. PT Raja Grafindo Persada.

Hoedaya, D. (2007). Kajian psikologi olahraga dari perspektif disiplin keilmuan. FPOK UPI.

Husdarta, H. J. S. (2011). Manajemen pendidikan jasmani. Alfabeta.

Iaia, F. M., Perez-Gomez, J., Thomassen, M., Nordsborg, N. B., Hellsten, Y., \& Bangsbo, J. (2011). Relationship between performance at different exercise intensities and skeletal muscle characteristics. Journal of Applied Physiology, 110(6), 1555-1563. https://doi.org/10.1152/japplphysiol.00420.2010

Kautsar, A., Sumardiyanto, S., \& Ruhayati, Y. (2018). Analisis fungsi manajemen organisasi olahraga (Studi kualitiatif pada pengurus daerah ikatan sport sepeda Indonesia Jawa Barat). Jurnal Terapan Ilmu Keolahragaan, 3(2), 41-45. https://doi.org/10.17509/jtikor.v3i2.10135

Khalsa, S. S. (2008). Pengajaran disiplin \& harga diri: Strategi, anekdot, dan pelajaran yang efektif untuk pengelolaan kelas yang sukses. Alih bahasa, Hartati Widiastuti. Jakarta: PT Indeks.

Koesoema, D. (2007). Pendidikan karakter: Strategi mendidik anak di zaman global. Grasindo.

Kusuma, G. N. A. (2013). Pengaruh pelatihan bayangan (shadow) bulutangkis terhadap peningkatan kelincahan dan kecepatan reaksi. Jurnal Ilmu Keolahragaan Undiksha, l(1). https://doi.org/10.23887/jiku.v1i1.1571

Mesnan, M., \& Antonius, F. (2019). Analisis manajemen pembinaan olahraga prestasi di KONI Pematang Siantar. Sains Olahraga : Jurnal Ilmiah Ilmu Keolahragaan, 3(1), 35. https://doi.org/10.24114/so.v3i1.13059

Miles, M. B., Huberman, A. M., \& Saldaña, J. (2014). Qualitative data analysis: A methods sourcebook. Sage.

Njoroge, P. M., \& Nyabuto, A. N. (2014). Discipline as a factor in academic performance in Kenya. Journal of Educational and Social Research, 4(1), 289. http://www.richtmann.org/journal/index.php/jesr/article/view/1847

Omote, M. J., Thinguri, R. W., \& Moenga, M. E. (2015). A critical analysis of acts of student indiscipline and management strategies employed by school authorities in public high schools in Kenya. International Journal of Education and Research, 3(12), 1-10. https://ijern.com/journal/2015/December-2015/01.pdf

Ouma, M. A., Simatwa, E. M. W., \& Serem, T. D. K. (2013). Management of pupil discipline in Kenya: A case study of Kisumu Municipality. Educational Research, 4(5), 374-386.

Park, K. J. (1998). Roosting ecology and behaviour of four temperate species of bat. University of Bristol.

Paturusi, A. (2012). Manajemen pendidikan jasmani dan olahraga. Rineka Cipta.

Proios, M., Athanailidis, I., Proios, M. P., \& Mavrovouniotis, F. (2013). Management of ethical problems in sport within the justice framework. International Journal of Sport Management, 
Recreation \& Tourism, 11, 42-62. https://doi.org/10.5199/ijsmart-1791-874X-11c

Rahman, T., \& Warni, H. (2017). Pengaruh latihan shadow 8 terhadap agility pada pemain bulutangkis PB. Mustika Banjarbaru usia 12-15 tahun. Multilateral Jurnal Pendidikan Jasmani Dan Olahraga, 16(1). https://doi.org/10.20527/multilateral.v16i1.3660

Setyobroto, S. (2002). Psikologi olahraga. Universitas Negeri Jakarta.

Siagian, S. P. (2005). Fungsi-fungsi manajerial. Bumi Aksara.

Stone, M. H., Sands, W. A., \& Stone, M. E. (2004). The downfall of sports science in the United States. Strength \& Conditioning Journal, 26(2). https://journals.lww.com/nscascj/Fulltext/2004/04000/The_Downfall_of_Sports_Science_in_the_United.15.aspx Sugiyono. (2010). Metode penelitian kuantitatif kualitatif dan $R \& D$. Alfabeta.

Sukadiyanto, S., \& Muluk, D. (2011). Pengantar teori dan metodologi melatih fisik. Lubuk Agung. Sukardi, H. M. (2008). Evaluasi pendidikan: Prinsip dan operasionalnya. Bumi Aksara. Tu'u, T. (2004). Peran disiplin pada perilaku dan prestasi siswa. Grasindo.

Zuriah, N. (2006). Metodologi penelitian sosial dan pendidikan: teori, aplikasi. Bumi Aksara. 